\title{
A pragmatic approach for rehabilitation of grazing lands and augmenting fodder availability in dry areas
}

\section{R. Meena*, Devendra Kumar, Khushyal Singh and S.P. Singh}

ICAR-Indian Institute of Farming Systems Research, Modipuram-250 110

*Email: 1rmeena63@gmail.com

\begin{abstract}
In dry areas, about 60 per cent of land is available for grazing consisting of permanent pasture lands, forest lands, fallow and cultivated wastelands. Thus, huge area fall under this category, this is not being scientifically managed. Sustainability of these lands is a serious concern for livestock production. Besides, productivity of animals in these areas entirely depends upon natural fodder resources. Therefore, an integration of improved fodder production systems on these lands is a hard pressing need. Hence, some rain-fed fodder based technologies have been suggested to overcome this problem, which may contribute to enhance and sustain the livelihood and fodder security in dry areas of the country. Moreover, silvi-pasture system could generate employment of 120 man days/ ha/year. Thus, available 50 million hectare of land can provide job to 20 million people annually in the country, additionally it helps in sorting out the fodder crunch during lean period.
\end{abstract}

Paper Cited: Meena, L.R., Kumar, D., Singh, K and Singh, S.P. (2017). A pragmatic approach for rehabilitation of grazing lands and augmenting fodder availability in dry areas. South Asian J. Food Technol. Environ., 3(1):516-520.

\section{Introduction}

India is basically an agrarian country with more than $65 \%$ of the total population living in rural areas. The rural population is dependent mainly on agriculture and animal husbandry for their sustenance. India with about $2.4 \%$ of the total world's geographical area sustains as much as $11.6 \%$ of the world's total livestock population (Islam et al., 2016) which plays an important role in country's rural economy and in meeting the demand for milk, milk products, meat, wool, hides and bone, manure etc. The limited fodder resources of the country unable to meet the requirement of ever increasing livestock population. At present projected demand for livestock feed is estimated to be 851.3 million tones of dry fodder and 530.5 million tones of green fodder (Vision 2050, IGFRI). The country faces a net deficit of $35.6 \%$ green fodder, $10.95 \%$ dry crop residues and $44 \%$ concentrate feed ingredients. Hence, this gigantic gap between the supply and demand of feed resources in the country can be bridged through proper utilization of available feed and fodder resources. In recent years, the population growth of both human and livestock has created a tremendous pressure on our land resources. The livestock population is increasing constantly whereas, the land under permanent pastures is also shrinking (12.4 million hectare). The extent of wastelands under various categories is estimated a sum of 173.6 mha. Water and wind eroded soils account for 144.1 mha, water logging soils $8.5 \mathrm{mha}$, saline soils $5.5 \mathrm{mha}$, sodic soil $3.9 \mathrm{mha}$, shifting cultivation 4.9 mha and ravine and gullies soils 4.0 mha. Development of wastelands requires lot of patience in accurate planning and management of conservation measures to revive the degraded and wasteland lands. About $4.9 \%$ of total cultivable and cultivable waste lands fall under 
fodder crops. Moreover, present land utilization in India does not allow to any more fertile and cultivable land to be put under fodder production. The problem of shortage of fodder lies in increasing the productivity of grasslands, improving the degraded rangelands, manipulating the livestock population and adaptation of grazing principles and management. Such programmes aim at direct economic gains and development needs of the country, such as reducing regional imbalance, improving living condition of the rural people, employment generation, increasing per capita income and finally it helps in enhancing social equity.

\section{Rural resource needs}

The production of food grains in India has increased from 50 million tonnes in 1951 to 273.38 million tonnes in 2016. There is need for increasing it further in view of the growing human population. The declining productivity of forests $(0.05 \mathrm{cu} \mathrm{m} / \mathrm{ha} / \mathrm{yr})$ against world average $(2.5 \mathrm{cu} \mathrm{m} / \mathrm{ha} / \mathrm{yr})$ and increase in area under degraded forests resulting in poor firewood supply forced dependence on crop biomass and animal dung for cooking fuel. This wasteful burning deprives the crop lands of the precious organic manure, so it is essential to restore organic matter in the soil through recycling of crop residues, bio-waste and green manuring for sustainable fodder production. The forage needs the growing animal population which shows another deficit scenario in the country, where farmers depend on forest grazing, tree leaf fodder and crop residues for nutrition supply in animals (Meena et al., 2015). In addition to migration there is a need for agroforestry system on such degraded lands for forage, firewood and timber to bridge the existing gap. Even on marginal agricultural lands, agroforestry is the most ideal option to support conservation, production and sustainability.

\section{Pasture /rangeland development}

The productivity of the marginal and sub-marginal lands over the years is decreasing due to tremendous pressure of human and livestock population. If these lands are not protected from the over grazing and exploitation, it may lead to fragile ecosystem. Therefore, there is a need to rehabilitate these lands through proper utilization of crops and trees species which help in conservation of natural resources such as soil, water, nutrients and solar radiation. Such attempt would supply a good amount of forage to our present animal population (512.05 million) in a sustainable manner. There are about 620 and 650 genera and 10000 and 18000 species of grasses and legumes, respectively in the world. Of these, only about 40 grasses and legumes are used to appreciable extent in the establishment of sown pastures. Moreover, it has been found that livestock prefer indigenous forage species in comparison to selected species of grasses and legumes despite the fact that indigenous species may be low in productivity and nutritive value, besides, over grazing beyond the carrying capacity deteriorate common grazing lands. The productivity of the natural pasture/range lands is less than $0.2 \mathrm{t} / \mathrm{ha} /$ year. Carrying capacity or stocking rate of these lands is less than 2 sheep/ha especially in semi-arid tracts of Rajasthan. The carrying capacity of pasture lands can be increased up to 6 sheep/ha through adoption of or grassland land is required once in three years. The productivity of these lands can be increased two-three folds by establishment of improved pasture/ range lands of perennial grasses and legumes in inter cultural operations in existing pasture lands, such as bunding, weeding, reseeding, bush cleaning, ploughing and application of sheep manure@10 t /ha in conjunction with use of chemical fertilizers@40:40:20 NPK kg/ha (Reference). Studies showed that sheep manure application in pasture association with fodder 
cum fuel trees. Multiple purpose fodder tree species should be planted at a close spacing and inter row spacing between rows can be utilized properly through cultivation of grasses and legumes to optimize the overall gains during the early growth period of trees with cut and carry system. Introduction of versatile grasses add nutrients into the soil providing excellent ground cover to eliminate weeds with the improvement of organic carbons and soil fertility status. In addition, planting of perennial legumes also nourishes the companion grasses and builds up soil fertility giving rise to green forages, which are rich in proteins and other mineral nutrients. Besides, balanced use of the fertilizers in pasture/ community grazing lands may not only increase the productivity but also increase the quality of the herbages and confers prolonged grazing span. Adoption of moisture conservation practices for reducing excess surface soil and water runoff losses and increase absorption of rain water in different soil layers thereby increases water use efficiency of pasture lands which is very essential for establishment new pasture on waste lands or barren lands.

\section{Trees on range lands}

Most of the range lands under the influence of monsoon type climate appear like savanna where trees and grasses grow together. Acacia nilotica, Prosopis cineraria and Prosopis julifora are also most frequent tree species on pasture lands those can be planted on community lands of adopted villages. Cattle rearing usually involve grazing on such range lands/pasturelands. In some of the cases fodder plants including legumes are also cultivated. The experimental results at Avikanagar on silvipasture showed that planting trees did not have any negative impact on fodder crops. However, yield of cultivated crops had decreased under tree because of competition for nutrients, water and light as a result, yield of associated crops was decreased but the supply of fuel, fodder and soil nutrients compensate the loss. The results of the investigation indicated that inter- cropping of Ardu with pasture species have no any adverse effects on under beanth grown crops. An organized farm of natural vegetation as silvipasture produces highest biomass with the application of 10 ton sheep manure/ ha /year as it was at par with $100 \%$ RDF application resulting in $25 \%$ saving of chemical fertilizers.

\section{Wastelands development for sustainable production}

There is wide gap between the availability and requirement of fuel wood and fodder resources in the country. At present, there is need about $242 \mathrm{~m}^{-3}$ of fuel wood and 1300 million ton of fodder annually. In the past decade, there is degradation of soil resources due to fast denudation of forest cover and excessive human and livestock pressure on earth. However, recognizing the importance of silvi-pasture intervention in the management of wastelands is realized as an alternative to combat the rising problems of fodder. The findings also revealed the potential of silvipasture for sustainable management of wastelands in the country is of paramount importance.

\section{Tree component}

In an integrated system, trees are grown to extract nutrients and water from deep layers of soil, there is continuous recycling of the organic matter in the soil by way of leaf fall and humus formation. Growth rates of trees are generally slow compared to herbaceous agricultural crops. Moreover, the long gestation period of trees and unpredictability of market rates prohibit the growers for their preferential cultivation. Therefore, the profit generated by tree based system cannot be compared with crop cultivation. Therefore, silvi-pasture system 
should be viewed as an investment for social security and environmental stabilization.

\section{Crop component}

Grasses have low and evenly distributed canopy and fibrous root systems with high soil binding capacity which makes them highly effective in conserving soil and water. Grasses and trees also permit 0 to $0.002 \% \mathrm{t} / \mathrm{ha} / \mathrm{yr}$ soil losses, while agricultural crops give rise 100 to $200 \mathrm{~mm}$ runoff and 2 to 5 tonnes soil loss per hectare. They also provide much- needed fodder to cattle, shelter and hideouts to birds and other several animals. Thus, silvi-pasture has paramount importance in management of grazing and wastelands of the country. Vegetative barriers have been devised to supplement mechanical interventions along with contours or on graded terraces to reduce soil and water erosion providing some fodder during the off-seasons.

\section{Silvi pasture systems}

Cultivation of some of the fodder trees in association with grasses/ grass - legume mixture has been standardized. The performance of under beneath crops did not find much difference in growth when they are grown with fodder trees on same piece of land. Similarly, grasses remain green and palatable for a longer period of time when they are grown in association with the fodder trees as compared to open space which helps in maintaining and improving animal health and productivity. The dry matter production of pasture land can be increased from existing level 2-2.5 to 10-12 ton/ha/annum. Under silvi- pasture system an increase in nitrogen, phosphorus and potassium was noticed despite the removal of grasses every year. It has been found that the initial organic matter content, available nitrogen, phosphorus and field capacity are improved by silvi-pasture over a period of 10 years. The grasses with trees as silvi-pasture were successfully used for soil conservation works in the ravines, grasses used for stabilization of contour bunds, bench terraces, earthen embankments and composite check-dams. Vegetative propagation on earth bunds for their stabilization or putting vegetative barriers across the slope has been found more effective in checking water erosion enhancing yield of fodder crops. The biological fixation of nitrogen is an enormous resource for maintaining and improving soil fertility. In addition to positive effects of the system it can also provide various outcomes such as, manure, stalking materials and fire wood. The silvipasture models give high benefit: cost ratio (1.42) years rotation. The systems show more than $20 \%$ of internal rate of return (IRR) at the farmer's management level with more than 600 trees/ha. Under the ravine conditions, this technology shows $18 \%$ IRR either it is managed by the Institute or by a farmer.

\section{Pasture/ rangelands resources for grazing animals and full filling local needs}

Pasture has also served as grazing land for pastoralists. The concept that historically evolved as a social mechanism to protect the livelihoods of the economically vulnerable section of pastoralists i.e. livestock- dependent rural communities secure their right to natural resources for subsistenance and livelihood purposes. Community managed pasture which traditionally found across India emerged in ancient times as an explicit acknowledgement of the vulnerability of certain groups in a stratified society, who therefore required some mechanisms that guaranteed their basic needs. In contrast with common lands belonging to the village and therefore in the control of power groups ancient laws dedicated these to divinity, thereby ensuring that the entire community had equal stake to their resources. Pasture/ rangelands used to be as a source of natural wealth like fuel, timber, roots and herbs. Many 
species are found within and outside the pastures and the traditional societies use them for a variety of livelihood needs to provide traditional non- timber forest products and subsistence goods to the people; nesting, roosting and foraging sites to the pest- controlling cavity nesting birds and other wild animals, protecting the species that offer sites for beehives and enhance the availability of honey, developing seedling orchards and seed production areas of ethno silvi-cultural species and sustaining the essential ecological processes and life support systems. Pastures provide vital grazing land for livestock, water, providing minor forest produce, medicinal plants and green cover for the villages where they resided. Thus, pasture plays a role in promoting and flourishing livestock based economy and growth of livestock rearing communities. Therefore, management of pasture is crucial for their own sustainable development. According to study, $41 \%$ livestock is dependent on pastures in dry districts of Rajasthan.

\section{Employment generation}

At present, there is no specific National Employment Policy in the country. However, an expert committee has been constituted for this purpose by the Government of India to address the issue of unemployment. The strategy indicating the creation of job opportunities in various fields is periodically assessed before launching of all the programmes. The silvipasture system promises sustainable level of employment to rural people in the activities of animal breeding, collection, processing and manufacture of value added products from trees and grasses and collection and trading of quality seed and other materials. In an average of 10 ear cycle, the establishment and management of silvipasture could generate engagement of 120ma days/ ha/yr. Thus, on 50 mha it can provide job to 20 million people annually however, other ancillary activities could provide job to another 5 million people additionally

\section{Conclusion}

In dry areas, about 60 per cent of land is available for grazing consisting of permanent pasture lands, forest lands, fallow and cultivated wastelands. Thus, huge area fall under this category which is not being scientifically managed. Sustainability of these lands is a serious concern for livestock production. Besides, productivity of animals in these areas entirely depends upon natural fodder resources. Therefore, an integration of improved fodder production systems on these lands is a hard pressing need. Hence, some rainfed fodder based technologies have been suggested to overcome this problem, which may contribute to enhance and sustain the livelihood and fodder security in dry areas of the country.

\section{References}

1. Islam, M.M., Shabana, A., Modi, R.J. and Wadhwani, K.N. (2016). Scenario of livestock and poultry in India and their contribution to national economy. International Journal of Science, Environment and Technology, 5(3): 95665.

2. Meena, L.R., Sanjeev Kumar, R.S. Yadav and Devendra Kumar (2015). Silvipasture Systems for Feed and Fodder Resource Development in Low Rainfall Areas of Rajasthan. Popular Kheti, 3(1):56-61.

3. Vision, (2050). ICAR-Indian Grassland and Fodder Research Institute, Jhansi. 